\begin{tabular}{lc}
\hline & ANNALES \\
& UNIVERSITATIS MARIAE CURIE-SKŁODOWSKA \\
LOL. V & SECTIO N \\
\hline
\end{tabular}

ISSN: 2451-0491 • e-ISSN: 2543-9340 • CC-BY 4.0 • DOI: 10.17951/en.2020.5.441-452

\title{
Rehabilitacja starości. Glottogeragogika jako wyzwanie wobec ageizmu
}

\section{Rehabilitation of Old Age. Glottogeragogy as a Challenge to Ageism}

\author{
Dariusz Piechota \\ Uniwersytet w Białymstoku. Wydział Filologiczny \\ pl. Niezależnego Zrzeszenia Studentów 1, 15-420 Białystok, Polska \\ darekpiechota@o2.pl \\ https://orcid.org/0000-0002-7943-384X
}

\begin{abstract}
The article is devoted to analysing and interpreting seniors as a new group of active students who learn foreign languages. Changes in the social structure confirm the thesis of sociologists that the $21^{\text {st }}$ century will be the period of emancipation of seniors. Active nestors in the public space will become not only depositaries of history, culture and tradition, but also take an important voice in intergenerational discussion, breaking negative stereotypes shaping the attitude of ageism. The involvement and interest of modern seniors in the course of classes organized by Third Age Universities prove that they are able to use the life opportunities offered by the retirement period. Therefore, the challenge for contemporary glottogeragogues is to develop programs, textbooks and teaching aids for learning foreign languages, taking into account the needs and interests of seniors.
\end{abstract}

Keywords: seniors; foreign languages; nestors; ageism; Third Age Universities; learning foreign languages 


\begin{abstract}
Abstrakt. Artykuł poświęcony jest charakterystyce seniorów jako nowej grupie aktywnych studentów uczących się języków obcych. Zmiany w strukturze społecznej potwierdzają tezę socjologów, że XXI wiek będzie okresem emancypacji seniorów. Aktywni nestorzy w przestrzeni publicznej staną się nie tylko depozytariuszami historii, kultury i tradycji, lecz także będą odgrywać ważną rolę w dyskusji międzypokoleniowej, przełamując negatywne stereotypy kształtujące postawę ageizmu. Zaangażowanie i zainteresowanie współczesnych seniorów zajęciami organizowanymi przez uniwersytety trzeciego wieku udowadnia, że grupa ta potrafi wykorzystywać możliwości życiowe oferowane przez okres emerytalny. Dlatego wyzwaniem dla współczesnych glottogeragogów jest opracowanie programów, podręczników i pomocy dydaktycznych do nauki języków obcych, z uwzględnieniem potrzeb i zainteresowań seniorów.
\end{abstract}

Słowa kluczowe: seniorzy; języki obce; nestorzy; ageizm; uniwersytety trzeciego wieku; nauka języków obcych

\title{
EMANCYPACJA SENIORÓW
}

Po emancypacji mniejszości etnicznych czy seksualnych XXI wiek będzie okresem emancypacji seniorów, którzy po przejściu na emeryturę nie rezygnują z aktywności fizycznej i intelektualnej. Obserwując transformacje zachodzące w społeczeństwie, można wyróżnić trzy czynniki sprzyjające emancypacji seniorów. Pierwszym z nich jest wydłużający się średni czas ludzkiego życia dzięki znaczącym osiągnięciom w zakresie medycyny i techniki. „Według danych GUS z 2008 roku średnia długość życia w Polsce dla mężczyzn wynosiła 71,3 lat, dla kobiet 80 lat" (Fąfrowicz, Laskowska-Szcześniak i Szcześniak 2014: 38). Na przestrzeni XX wieku przeciętne trwanie życia wydłużyło się o 18 lat dla kobiet i o 15 lat dla mężczyzn (tamże: 38). Spadająca liczba urodzeń oraz wzrastająca liczba seniorów sprawia, że jesteśmy społeczeństwem w zaawansowanej starości demograficznej. Prawdopodobnie w 2030 roku „ludzie powyżej 65. roku życia w naszym kraju będą stanowili 23,8\% społeczeństwa", dlatego uwaga mass mediów powinna koncentrować się na potrzebach i zainteresowaniach osób w „późnej młodości” (tamże).

Wielu współczesnych emerytów, w przeciwieństwie do poprzedniego pokolenia, nie wycofuje się z przestrzeni publicznej. Co więcej, nie zamykają się w kręgu rodzinnym, lecz poszukują nowych przyjaciół, z którymi mogą rozwijać swoje zainteresowania. Okres starości przestaje być traktowany przez nich jako czas izolacji i koncentracji wyłącznie na życiu rodzinnym. Wielu z nich stara się prowadzić aktywny styl życia, uczęszczając m.in. na specjalne zajęcia sportowe, organizowane w lokalnych siłowniach czy innych ośrodkach sportowych. Coraz większą popularnością cieszą się uniwersytety trzeciego wieku (UTW), w których z roku na rok wzrasta liczba studentów (Stanowska 2014: 125). W przeciwieństwie do młodego narcystycznego pokolenia, niejednokrotnie lekceważącego potrzebę 
kształcenia się i marzącego o szybkiej karierze, współczesnym seniorom bliska wydaje się być koncepcja „uczenia się przez całe życie” (Jaroszewska 2013: 173), oddająca główne tendencje polityki Unii Europejskiej w sferze edukacji i relacji społecznych. Uczestnictwo w różnorodnych zajęciach umożliwia seniorom zdobywanie nowych kompetencji, pomaga przystosować się do zmieniających się warunków życia, ułatwia wchodzenie w nowe role społeczne. UTW propagują koncepcję pozytywnego i zdrowego starzenia. Poprzez organizowanie słuchaczom czasu wolnego umożliwiają im kontakt z rówieśnikami i motywują ich do samorealizacji (tamże: 79). Słusznie więc konstatuje Elżbieta Dubas:

Życie nie ma już tylko polegać na jego dożywaniu, ale ma być wartościowe, wypełnione doświadczeniami, które wzbogacają osobowość człowieka i podnoszą jakość jego życia. By osiągnąć wysoką jakość życia, potrzebna jest właśnie edukacja. Jest ona swoistym instrumentem usprawniającym życie człowieka współczesnych społeczeństw wysokorozwiniętych. (Dubas 2005: 154)

UTW przełamują nie tylko negatywne stereotypy na temat seniorów, ale również stanowią istotny krok w stronę dialogu międzykulturowego. Ponadto kształtują postawę otwartości wobec odmienności i różnorodności kultur. Wśród zajęć proponowanych w ramach oferowanego przez nie kształcenia coraz większą popularnością cieszą się kursy języków obcych (głównie języka angielskiego), a do czynników motywujących seniorów do nauki należą: możliwość posługiwania się językiem obcym w trakcie podróży; czytanie literatury obcojęzycznej; umiejętność przetłumaczenia słów piosenek, sloganów reklamowych, nazw produktów (Róg 2011: 122-130). Zainteresowanie kursami języka obcego wśród seniorów wymaga reorganizacji systemu kształcenia osób po 60. roku życia, obejmującej zarówno metody i formy pracy, jak i nauczycieli - wykwalifikowanych glottogeragogów ${ }^{1}$.

\section{CHARAKTERYSTYKA SENIORÓW JAKO STUDENTÓW JĘZYKA OBCEGO}

Nie ulega wątpliwości, że dotychczasowy podział uczących się języka obcego na trzy grupy zgodnie z systemem szkolnym: dzieci, młodzież, dorośli (Lipińska 2006: 57-58), stracił na aktualności. Inaczej języka obcego będzie uczył się nieustannie zdobywający nowe doświadczenia i mający niezwykle chłonny umysł dwudziestolatek niż sześćdziesięciolatek, który niekiedy miewa problemy z zapamiętywaniem i kodowaniem nowych informacji. Dlatego nauczanie seniorów

1 Glottogeragogika zajmuje się nauczaniem języków obcych osób w okresie starości. Łączy w sobie dwie dyscypliny naukowe: glottodydaktykę i geragogikę (Jaroszewska 2013: 28-33). 
wymaga szczególnych umiejętności oraz głębokiej wiedzy z różnych dziedzin (tamże: 62). Lektor uczący nestorów powinien dysponować gruntowną wiedzą na temat regresywnych przemian zachodzących w organizmie swoich uczniów, gdyż wiele z nich ma wpływ na proces uczenia się. Zarówno czynniki biologiczne (fizjologiczne) czy poznawcze, jak i emocjonalne oraz społeczne odgrywają istotną rolę w procesie akwizycji języka docelowego.

Rozpoczynając charakterystykę czynników biologicznych, warto pamiętać, że u osób po 60. roku życia następują zmiany zachodzące w układzie kostno-stawowym; maleje masa kostna, pogarsza się struktura kości, pojawiają się zmiany zwyrodnieniowe (Fąfrowicz, Laskowska-Szcześniak i Szcześniak 2014: 40), które mogą mieć negatywny wpływ na koncentrację w trakcie zajęć. U seniorów obserwuje się również zaburzenia równowagi i starczowzroczność (prebyopia), polegającą na utracie ostrości widzenia i pogarszającym się widzeniu z bliskiej odległości. Zaburzenie to bywa szczególnie uciążliwe w warunkach niewystarczającego oświetlenia (tamże: 41), dlatego glottogeragog powinien pamiętać o dobrym świetle w sali, w której odbywają się zajęcia. Istotne jest też dostosowanie wielkości czcionki oraz rozmiaru ilustracji. Materiały przygotowywane przez nauczyciela muszą być czytelne i wyraziste. Po 65. roku życia postępuje starczy niedosłuch (presbyacusis) oraz tzw. zjawisko „podkręcania głośności”, polegające na odbieraniu dźwięków wyższych jako głośniejszych niż są w rzeczywistości. Pojawiający się hałas utrudnia rozumienie mowy, dlatego nagrania dotyczące rozwijania umiejętności słuchania ze zrozumieniem (listening comprehension) powinny być specjalnie przygotowane dla studentów UTW. Zaleca się wyeliminowanie wszelkich dźwięków z tzw. tła.

W strukturze układu nerwowego u seniorów dochodzi do zmniejszenia liczby neuronów i wytwarzanych neuroprzekaźników, co wydłuża czas reakcji odruchowych (tamże), o czym warto pamiętać przy wykorzystywaniu metod niekonwencjonalnych, takich jak metoda reagowania całym ciałem (Total Physical Response - TPR) (Seretny 2006: 143-146). Nasilające się objawy otępienne mogą być przyczyną problemów w realizacji poleceń nauczyciela, których wykonanie wymaga natychmiastowej reakcji słuchacza. Obniżająca się wydolność fizyczna (od 25. roku o około 10\% na dekadę) (Fąfrowicz, Laskowska-Szcześniak i Szcześniak 2014: 49) może stanowić blokadę w odgrywaniu ról i scenek sytuacyjnych związanych z wykorzystaniem ruchu w trakcie nauki języka obcego. $Z$ wiekiem nasila się również mechanizm interferencji, przejawiający się nakładaniem informacji nieistotnych na informacje ważne z perspektywy celu dydaktycznego (Jaroszewska 2013: 68). Mechanizm ten może stanowić blokadę w trakcie wykonywania ćwiczeń rozwijających umiejętność czytania ze zrozumieniem (reading comprehension), w szczególności jeśli chodzi o rozumienie globalne szczegółowe. W związku z postępującą 
interferencją seniorzy mogą mieć także kłopot z rozróżnieniem faktu od opinii, co bywa częstym problemem wśród uczniów szkół ponadpodstawowych. U osób powyżej 65. roku życia następuje często zaburzenie cyklu okołodobowego, przejawiające się m.in. w problemach ze snem, zaburzeniach trawienia, trudnościach z zapamiętywaniem i koncentracją uwagi (tamże: 53).

Istotną rolę w procesie akwizycji języka obcego odgrywają czynniki emocjonalne i społeczne. Transformacje zachodzące w społeczeństwie na skutek emigracji zarobkowej oraz zaniku rodzin wielopokoleniowych wpływają negatywnie na samopoczucie osób skazanych na samotność (Sobstyl 2014: 371-382; Stanowska 2014: 123). Nowoczesne technologie, zmiany społeczno-obyczajowe, konsumpcyjny styl życia i kult młodości przyczyniają się do alienacji osób starszych, które odczuwają tęsknotę za kontaktami z innymi ludźmi. Za ilustrację tego zjawiska mogą służyć wyniki badań brytyjskiej organizacji Help the Aged, przeprowadzonych w 2007 roku, z których wynika, że 13\% osób powyżej 65. roku życia cierpi na samotność (Stanowska 2014: 122). Kontakt z rówieśnikami inspiruje do bycia aktywnym, zapewniając poczucie sensu własnej egzystencji poprzez odkrywanie nowych ról społecznych (np. uczeń senior). Zauważa się, że mężczyźni gorzej znoszą przejście na emeryturę, gdyż jest to koniec ich aktywności zawodowej, a nowy etap życia stawia przed nimi zadania, do których wypełnienia nie zostali przygotowani (Zierkiewicz 2014: 24). Uczestnictwo w zajęciach organizowanych przez UTW nie tylko promuje postawę aktywnego starzenia się, ale również umożliwia nawiązywanie nowych kontaktów towarzyskich.

Mimo że z wiekiem maleje plastyczność organów odpowiedzialnych za opanowanie wymowy języka obcego, seniorzy posiadają wiele cech istotnych w procesie akwizycji języka obcego. W trakcie nauki wykorzystują zasadę świadomego uczenia się i stosowania reguł (np. przy indukcyjnym nauczaniu gramatyki). Cechuje ich zdolność myślenia abstrakcyjnego oraz dociekliwość językowa. W przeciwieństwie do młodzieży seniorzy są bardziej cierpliwi i sumienni oraz silnie zmotywowani. Uczestnictwo w kursie językowym zaspokaja ich potrzeby poznawcze, emocjonalne i społeczne (Jaroszewska 2013: 41).

\section{CHARAKTERYSTYKA GLOTTOGERAGOGA}

Dobry nauczyciel zdaniem słuchaczy UTW powinien być: cierpliwy, spostrzegawczy, otwarty, wyrozumiały, posiadać poczucie humoru i kompetencje językowe (tamże: 221). To również przewodnik pozwalający zrozumieć inną, niekiedy odmienną kulturę poprzez budowanie postawy otwartości wobec szeroko rozumianego Innego (Fiema 2016: 29-30). Glottogeragog powinien być empatyczny i starać się zrozumieć seniorów, ich uczucia i potrzeby. Do jego 
podstawowych zadań należy nie tylko organizacja procesu nauczania, ale i nieustanne motywowanie uczących się oraz udzielanie im wsparcia i pomocy. Analizując rodzaje stylów kierowania procesem nauczania (Komorowska 2002: 81-83), wydaje się, że dla seniorów najbardziej odpowiedni jest styl uczestniczący (partycypacyjny), gdyż zachęca ich do współtworzenia zajęć językowych, co jest istotne również z perspektywy psychologicznej. Seniorzy czują się odpowiedzialni za współudział w tworzeniu zajęć, co wpływa pozytywnie na ich motywację do nauki. Nauczyciel, jako przewodnik w nowoczesnym świecie, powinien wskazywać uczestnikom kursu nowe możliwości samorealizacji oraz wspierać ich we wszelkich formach aktywności. Dodatkowo, jak wspomniano wcześniej, niezbędna jest wiedza z zakresu andragogiki. Nauczyciel powinien być świadomy zmian zachodzących w organizmie seniorów oraz ich potencjalnego wpływu na proces akwizycji języka obcego.

Warto też pamiętać, aby przestrzeń edukacyjna była dostosowana do uczestników kursu. Kluczową rolę odgrywa dobre oświetlenie sali i nagłośnienie; ławki należy ustawić w podkowę, tak aby wszyscy uczniowie widzieli się nawzajem. W trakcie pracy frontalnej nauczyciel powinien mówić głośno i wyraźnie, nawiązując kontakt wzrokowy ze słuchaczami. Podczas pracy indywidualnej i grupowej należy monitorować pracę poszczególnych uczniów czy zespołów, poprawiając błędy i motywując do dalszego działania.

\section{PROGRAM NAUCZANIA JĘZYKA OBCEGO DLA SENIORÓW}

Przed rozpoczęciem kursu języka obcego dla seniorów fundamentalną kwestią staje się wybór odpowiedniego programu nauczania. Anna Jaroszewska (2013: 288-289), uwzględniając strukturę takich programów, twierdzi, że dla osób „W późnej młodości” najlepszy jest program spiralny, koncentrujący się wokół określonego materiału gramatycznego i leksykalnego, niezbędnego do komunikacji z użytkownikami danego języka. Powinien on mieć charakter utylitarny i skupiać się na doskonaleniu sprawności mówienia oraz rozumienia ze słuchu. Uwzględniając treści nauczania, idealnym modułem wydaje się być program „mieszany", będący kompilacją różnych elementów (Janowska 2006: 168). Powinien być przede wszystkim przyjazny uczniom seniorom, tj.: przekazywać praktycznie przydatną wiedzę i umiejętności; prezentować atrakcyjne treści nauczania i formy pracy; jasno precyzować umiejętności, jakie nabędą słuchacze na koniec kursu; umożliwiać indywidualną pracę w przypadku choroby bądź nieobecności. Uwzględniając czynniki związane z motywacją do nauki, niezwykle przydatne stają się programy: funkcjonalny, sytuacyjny i tematyczny (tamże: 167). Pierwszy z nich wiąże się z praktycznymi umiejętnościami, które uczący się będzie mógł 
wykorzystać w życiu prywatnym (np. podczas podróży). Drugi kładzie nacisk na konkretne sytuacje, w których senior będzie umiał się posługiwać językiem obcym (np. na lotnisku, w kawiarni). Program ten jest szczególnie popularny w krótkich kursach, organizowanych dla słuchaczy wybierających się do kraju nauczanego języka. Program tematyczny, często stosowany w nauczaniu dorosłych, pozwala na opanowanie niezbędnej leksyki, umożliwiającej komunikację z osobami posługującymi się danym językiem. Istotny wydaje się wybór tematyki dostosowanej do grupy wiekowej uczestników kursu. Na pewno więcej jednostek lekcyjnych należy poświęcić słownictwu związanemu z podróżowaniem, ograniczając leksykę m.in. związaną z tematyką szkolną. Program ten powinien pomijać także tematy tabu związane z przemijaniem i śmiercią, gdyż może to wpłynąć negatywnie na samopoczucie uczących się. Przy konstruowaniu programu nie należy zapominać o elementach realioznawczych, którymi szczególnie zainteresowani są seniorzy. Nabywanie kompetencji kulturowej wpływa nie tylko na przełamywanie stereotypów kulturowych, ale też stwarza szansę lepszego zrozumienia świata współczesnego (Fiema 2016: 27), przeciwdziała dyskryminacji i wykluczeniu społecznemu osób odbiegających od popularnych wzorców zachowań.

\section{METODY NAUCZANIA SENIORÓW JĘYYKÓW OBCYCH}

Większość seniorów uczęszczających na kursy języka obcego, organizowane w ramach zajęć oferowanych przez UTW, bazuje na doświadczeniach wyniesionych ze szkoły podstawowej i średniej, dlatego bliska jest im metoda gramatyczno-tłumaczeniowa, koncentrująca się na poznaniu systemu gramatycznego oraz opanowaniu słownictwa języka docelowego (Seretny 2006: 136-137). Z punktu widzenia współczesnych metod konwencjonalnych i niekonwencjonalnych metoda ta wydaje się archaiczna, gdyż w centrum jej zainteresowania znajdują się kształcenie umiejętności czytania ze zrozumieniem oraz tłumaczenia. Wstąpienie do Unii Europejskiej, rozwój turystyki oraz migracja zarobkowa zmieniły priorytety w nauce języka obcego wśród seniorów, dla których najważniejsze okazały się być umiejętności słuchania i mówienia (listening comprehension and speaking). Czytanie tekstów literackich czy publicystycznych w języku docelowym przestało być nadrzędnym celem nauki. Mimo że metoda gramatyczno-tłumaczeniowa wydaje się sztuczna, trudno ją wyeliminować na niższych poziomach kursu językowego dla seniorów. Wprowadzenie na pierwszych lekcjach elementów typowych dla metody audiolingwalnej czy kognitywnej może zniechęcić uczestników do kontynuowania nauki. Pamiętajmy, że dorośli - w przeciwieństwie do dzieci czy młodzieży - stosują zasadę świadomego uczenia się i stosowania reguł. Jako osoby dociekliwe wielokrotnie na początku kursu tłumaczą każde słowo, dlatego 
warto wprowadzać elementy tłumaczenia dydaktycznego, które ostatnio przeżywa renesans w najnowszej metodyce nauczania języków obcych² ${ }^{2}$.

Tłumaczenie dydaktyczne jako naturalne działanie komunikacyjne spełnia istotne funkcje w nauczaniu seniorów. Po pierwsze, jak pisze Anna Dunin-Dudkowska (2016: 101), uatrakcyjnia proces kształcenia i podnosi jego efektywność „przez wykorzystywanie naturalnej skłonności uczących się do przekładania nowych treści na język ojczysty". Po drugie, motywuje seniorów do dalszej nauki, gdyż mogą na bieżąco sprawdzić postępy w posługiwaniu się językiem obcym poprzez tłumaczenie m.in. ulotek reklamowych, menu, tekstów piosenek itd. Dodatkowo ćwiczenia typu sandwiching (przekładaniec językowy) (tamże: 108-110), będące rodzajem gier i zabaw dydaktycznych, pozwalają nie tylko na przełamywanie blokady w posługiwaniu się językiem obcym, ale również utrwalają konstrukcje gramatyczne (typu: powitania, pożegnania itd.). Dlatego na poziomach niższych warto wykorzystywać metodę gramatyczno-tłumaczeniową, dzięki której wśród uczestników wzrasta zarówno motywacja do nauki, jak i pewność siebie w posługiwaniu się językiem obcym. W trakcie kursu oczywiście nie rezygnujemy z niekonwencjonalnych metod nauczania. Podczas lekcji powtórzeniowych warto wprowadzać elementy metody audiolingwalnej, choćby niezwykle popularnej w ostatnich czasach tzw. metody Callana, o ile uczestnicy opanowali określone zwroty i frazy. Ćwiczenia typu tworzenie krótkich dialogów w języku obcym, zadawanie pytań i udzielanie odpowiedzi (przy całkowitym wyeliminowaniu języka ojczystego) czy stosowanie gier leksykalnych (takich jak wąż literowy, rebusy, zabawa państwa-miasta, krzyżówki) wpływają pozytywnie na akwizycję języka obcego. Od poziomu A2 należy wprowadzać metodę kognitywną pod warunkiem, że uczestnicy kursu opanowali leksykę oraz struktury gramatyczne z poziomu A1.

\section{KONCEPCJA PODRĘCZNIKA KURSOWEGO DLA SENIORÓW}

Wyzwaniem dla współczesnej glottodydaktyki w Polsce jest opracowanie podręczników do nauki języków obcych dla seniorów. Obecnie dostępne pomoce dydaktyczne dotyczą języka angielskiego i adresowane są raczej do osób, które uczyły się już wcześniej tego języka, a teraz pragną powrócić do nauki samodzielnie (relearning). Na rynku polskim, oprócz fiszek dla nestorów, dostępne są dwa podręczniki. Pierwszy z nich to Angielski dla seniora. Kurs języka angielskiego z płyta MP3 Alisy Mitchel Masiejczyk i Aliny Laskowskiej, składający się z trzydziestu jednostek lekcyjnych, z których połowa to zagadnienia

2 O czym świadczy choćby tom Ttumaczenie dydaktyczne w nowoczesnym kształceniu językowym (Lipińska i Seretny red. 2016). 
gramatyczne, pozostałe zaś to zagadnienia leksykalne przedstawione $\mathrm{w}$ formie dialogów. Ich tematyka obejmuje m.in. takie zagadnienia, jak: wizyta lekarska, wyjazd do sanatorium, zalety nordic walking, wizyta u przyjaciół w domku letniskowym, promocja w supermarketach, obsługa komputera. Podręcznik ten niestety utrwala negatywne stereotypy dotyczące osób starszych ${ }^{3}$. Każdy rozdział zawiera dodatkowe trzy ćwiczenia utrwalające materiał gramatyczny bądź leksykalny oraz klucz do ćwiczeń. Nasycenie kursu zagadnieniami gramatycznymi (które nie są powiązane z częścią leksykalną) może zniechęcić seniora. Plusem Angielskiego dla seniora jest większa czcionka oraz pojawiające się krzyżówki w rozdziałach poświęconych zagadnieniom leksykalnym.

Drugim dostępnym podręcznikiem na rynku polskim jest Angielski dla seniorów. Kurs poczatkowy Joanny Szyke i Katarzyny Zimnoch. Składa się on z dwunastu części, a każda z nich - z trzech jednostek lekcyjnych. Jak zaznaczyły we wstępie autorki, podstawową techniką uczenia się zwrotów i wyrażeń jest ich systematyczne powtarzanie za lektorem, dlatego w podręczniku dominuje metoda audiolingwalna, zgodnie z którą uczniowie uczą się schematów i zdań wzorcowych poprzez ich automatyzację. W Angielskim dla seniorów dominuje gramatyka, a zagadnienia leksykalne $\mathrm{w}$ większości stanowią listę słówek do zapamiętania. Czytanie jest skoordynowane ze słuchaniem; w dziesięciu częściach pojawia się dialog (nagrany na płycie i przetłumaczony w kluczu) bez dodatkowych ćwiczeń sprawdzających zrozumienie przeczytanej (bądź wysłuchanej) rozmowy. Tylko w jednej lekcji pojawia się zadanie, do którego przygotowano ćwiczenie typu prawda-fałsz. Do każdej sekcji dołączono tekst (niestety, wyłącznie w języku polskim) wprowadzający element realioznawczy ${ }^{4}$ (m.in. postać królowej Elżbiety, tajemniczy krąg Stonehenge, waluta Wielkiej Brytanii, Bank Holiday).

Oba podręczniki przeznaczone są do samodzielnej nauki, dlatego posługiwanie się nimi jako materiałem wiodącym w trakcie kursu językowego dla seniorów okazuje się niezwykle trudne, gdyż brakuje ćwiczeń rozwijających sprawności zarówno produktywne, jak i receptywne. W książkach tych nie ma ćwiczeń komunikacyjnych do pracy w parach i grupach.

3 W centrum zainteresowania seniorów znajdują się najbliższa rodzina i promocje w supermarketach; osoby wyjeżdżające do sanatorium ostrzegane są przed natrętnymi mężczyznami szukającymi towarzystwa rówieśniczek. Aktywny styl życia seniorów dotyczy wyłącznie sportu (zachęcanie do rozpoczęcia nordic walking). Z badań przeprowadzonych przez Annę Jaroszewską wynika, że dla seniorów istotny w kursie jest element realioznawczy. Niestety, z podręcznika Angielski dla seniora nie dowiemy się nic na temat obyczajów, świąt czy sławnych pisarzy, piosenkarzy i aktorów pochodzących z Anglii bądź Stanów Zjednoczonych.

4 Niestety, ich tematyka nie została skorelowana z leksyką dominującą w danym dziale. W części poświęconej zdrowiu (wizyta u lekarza i w aptece, nazwy chorób, wypadki) zamieszczono tekst na temat kuchni brytyjskiej. 
Opracowując podręcznik kursowy, warto skoncentrować się na budowaniu pozytywnego wizerunku starości. Jego główny bohater to aktywny senior, który potrafi wskazać perspektywy własnego rozwoju; to osoba, która otwiera się na multikulturowość i nowoczesne zjawiska społeczne (tabela 1).

Tabela 1. Przykładowy katalog tematyczny oraz zagadnienia, w centrum których znajduje się senior

\begin{tabular}{|c|c|}
\hline Człowiek & $\begin{array}{l}\text { - teksty opisujące uczestników kursu językowego dla seniorów (wygląd } \\
\text { zewnętrzny, osobowość, cechy charakteru) } \\
\text { - opisywanie nowych przyjaciół }\end{array}$ \\
\hline Życie codzienne & - teksty ukazujące dzień z życia aktywnego seniora \\
\hline $\begin{array}{l}\text { Sposoby spędzania } \\
\text { wolnego czasu }\end{array}$ & $\begin{array}{l}\text { - typowe i nietypowe zainteresowania seniorów } \\
\text { - poznawanie nowych osób poprzez portale społecznościowe }\end{array}$ \\
\hline Mieszkanie & $\begin{array}{l}\text { - opisywanie swojego mieszkania, ulubionego pokoju lub miejsca, do } \\
\text { którego zaprasza się przyjaciół }\end{array}$ \\
\hline Praca & - aktywni seniorzy na rynku pracy (Czy warto pracować na emeryturze?) \\
\hline Edukacja & $\begin{array}{l}\text { - teksty na temat popularności UTW } \\
\text { - dyskusja na temat ulubionych zajęć } \\
\text { - planowanie nowych zajęć na kolejny rok akademicki }\end{array}$ \\
\hline Żywienie & $\begin{array}{l}\text { - teksty dotyczące zdrowej żywności i posiłków regionalnych } \\
\text { - przygotowywanie dwujęzycznego menu z lokalnymi potrawami } \\
\text { - zamawianie posiłków, rozmowa przy stole } \\
\text { - ulubione potrawy i przepisy kulinarne } \\
\text { - ulubione restauracje, kawiarnie }\end{array}$ \\
\hline Zakupy & $\begin{array}{l}\text { - teksty dotyczące zakupów online } \\
\text { - instrukcja obsługi bankomatu }\end{array}$ \\
\hline Kultura & $\begin{array}{l}\text { - teksty dotyczáce aktywnych artystów po 60. roku życia } \\
\text { - ulubieni artyści } \\
\text { - tłumaczenie tytułów filmów } \\
\text { - tłumaczenie tekstów piosenek } \\
\text { - sporządzanie listy książek, które warto przeczytać na emeryturze } \\
\text { - opowiadanie o ulubionej lub ostatnio przeczytanej książce } \\
\text { - opisywanie swojego ulubionego filmu lub serialu }\end{array}$ \\
\hline Podróżowanie & $\begin{array}{l}\text { - teksty dotyczące popularnych miejsc odwiedzanych przez seniorów } \\
\text { - prezentacja atrakcji własnego miasta } \\
\text { - rozmówki na lotnisku, dworcu kolejowym itd. } \\
\text { - kupowanie biletu, dokonywanie rezerwacji online }\end{array}$ \\
\hline Zdrowie & $\begin{array}{l}\text { - teksty o charakterze popularnonaukowym, np. jak radzić sobie ze } \\
\text { stresem, przygnębieniem } \\
\text { - domowe sposoby na leczenie częstych chorób, np. przeziębienia, bólu } \\
\text { żołądka, głowy itd. }\end{array}$ \\
\hline Sport & $\begin{array}{l}\text { - sławni sportowcy po 60. roku życia } \\
\text { - ankiety dotyczące wyboru odpowiedniego sportu w zależności od } \\
\text { kondycji fizycznej i psychicznej }\end{array}$ \\
\hline
\end{tabular}

Źródło: opracowanie własne. 
Zgodnie z założeniami gramatyki pedagogicznej zagadnienia gramatyczne powinny być powiązane z materiałem leksykalnym, dlatego np. przy opisywaniu czasu wolnego należy wprowadzić konstrukcję czasu teraźniejszego Present Simple, a przy planowaniu podróży - konstrukcję be going to. Tworząc podręcznik kursowy, nie można zapominać o elementach realioznawczych, które warto skonfrontować z tradycją rodzimą (wskazując na podobieństwa i różnice). W przypadku zadań poświęconych rozwijaniu umiejętności słuchania ze zrozumieniem na niższych poziomach trzeba pamiętać, aby wyeliminować wszelkie dźwięki zakłócające odbiór. Z perspektywy technicznej należy dodać, że czcionka w podręczniku powinna być powiększona w stosunku do typowej, a wszelkie istotne reguły do zapamiętania powinny być zapisane pogrubionym drukiem. Jednostki tematyczne nie mogą być przeładowane materiałem leksykalno-gramatycznym, aby nie zniechęcić uczniów do nauki. Należy pamiętać, że uczenie się języka obcego przez seniorów - oprócz wymiaru pragmatycznego (związanego choćby z językowym przygotowaniem do podróży) - propaguje ideę uczenia się przez całe życie, które ma być źródłem przyjemności i radości.

\section{ZAKOŃCZENIE}

Zmiany zachodzące w strukturze społecznej potwierdzają tezę socjologów, że wiek XXI będzie okresem emancypacji seniorów. Aktywni nestorzy w przestrzeni publicznej staną się nie tylko depozytariuszami historii, kultury i tradycji (Potent-Ambroziewicz 2013: 101), lecz także zabiorą istotny głos w dyskusji międzypokoleniowej, przełamując negatywne stereotypy kształtujące postawę ageizmu ${ }^{5}$. Aktywni studenci seniorzy udowadniają, że są oni zdolni do współzawodnictwa i potrafią optymalnie wykorzystać możliwości życiowe, jakie daje im okres emerytury. Dlatego wyzwaniem dla współczesnych glottogeragogów jest opracowanie programów, podręczników i pomocy dydaktycznych do nauki języków obcych, które będą uwzględniać potrzeby i zainteresowania seniorów.

5 Ageizm - dyskryminacja i uprzedzenia ze względu na starszy wiek; funkcjonuje także spolszczony termin „wiekizm” (Zierkiewicz 2014: 21). 


\section{BIBLIOGRAFIA}

Dubas, E. (2005). Geragogika - dyscyplina pedagogiczna o edukacji w starości i do starości. W: A. Fabiś (red.), Seniorzy w rodzinie, instytucji i społeczeństwie. Wybrane zagadnienia wspótczesnej gerontologii (s. 143-155). Sosnowiec: Wydawnictwo Wyższej Szkoły Zarządzania i Marketingu.

Dunin-Dudkowska, A. (2016). Tłumaczenie profesjonalne i dydaktyczne a glottodydaktyka. W: E. Lipińska, A. Seretny (red.), Ttumaczenie dydaktyczne w nowoczesnym kształceniu językowym (s. 95-112). Kraków: Księgarnia Akademicka.

Fąfrowicz, B., Laskowska-Szcześniak, M., Szcześniak, A. (2014). Odmienności terapeutyczne w wieku podeszłym. W: E. Łoch, E. Flis-Czerniak, G. Wallner, D. Piechota (red.), Między literaturą a medycyną. Część 8: Starość i inne problemy egzystencjalne $w$ badaniach interdyscyplinarnych (s. 37-51). Lublin: Wydawnictwo UMCS.

Fiema, M. (2016). Kształcenie językowe osób w wieku późnej dorosłości - proces standardowy czy wyzwanie? Jezyki obce w szkole, nr 4, 24-31.

Janowska, I. (2006). Przygotowanie kursu językowego - programy nauczania. W: E. Lipińska, A. Seretny (red.), Z zagadnień dydaktyki języka polskiego jako obcego (s. 155-175). Kraków: TAiWPN Universitas.

Jaroszewska, A. (2013). Nauczanie języków obcych seniorów w Polsce. Analiza potrzeb i możliwości w aspekcie międzykulturowym. Kraków: Oficyna Wydawnicza Impuls.

Komorowska, H. (2002). Metodyka nauczania języków obcych. Warszawa: Wydawnictwo Fraszka Edukacyjna.

Lipińska, E. (2006). Czynniki wpływające na proces uczenia się. W: E. Lipińska, A. Seretny (red.), Z zagadnień dydaktyki języka polskiego jako obcego (s. 57-77). Kraków: TAiWPN Universitas.

Lipińska, E., Seretny, A. (red.). (2006). Z zagadnień dydaktyki języka polskiego jako obcego. Kraków: TAiWPN Universitas.

Potent-Ambroziewicz, M. (2013). Starość w języku młodzieży współczesnej. Lublin: Wydawnictwo UMCS.

Róg, T. (2011). O źródłach motywacji w kontekście edukacji językowej dorosłych. Neofilolog Czasopismo Polskiego Towarzystwa Neofilologicznego, nr 37, 121-132.

Seretny, A. (2006). Metody nauczania języków obcych a nauczanie języka polskiego zarys. W: E. Lipińska, A. Seretny (red.), Z zagadnień dydaktyki języka polskiego jako obcego (s. 131-154). Kraków: TAiWPN Universitas.

Sobstyl, K. (2014). Językowy obraz samotności w wypowiedziach osób starszych. W: E. Łoch, E. Flis-Czerniak, G. Wallner, D. Piechota (red.), Między literatura a medycyna. Część 8: Starość i inne problemy egzystencjalne w badaniach interdyscyplinarnych (s. 371-382). Lublin: Wydawnictwo UMCS.

Stanowska, M. (2014). Samotność osób starszych. W: E. Łoch, E. Flis-Czerniak, G. Wallner, S. Bobowski (red.), Między literaturą a medycyną. Część 10: Człowiek wobec sytuacji ekstremalnych (s. 121-127). Lublin: Wydawnictwo UMCS.

Zierkiewicz, E. (2014). Ageizm. W: M. Rudaś-Grodzka (red.), Encyklopedia gender. Pteć w kulturze (s. 22-24). Warszawa: Wydawnictwo Czarna Owca. 